\title{
McNamara analysis cephalometric parameters in White-Brazilians, Japanese and Japanese-Brazilians with normal occlusion
}

\author{
Juliana Moura STORNIOLO-SOUZA ${ }^{1}$ \\ (iD https://orcid.org/0000-0002-6946-9718 \\ Maria Pia SEMINARIO ${ }^{1} \bowtie$ \\ (D) https://orcid.org/0000-0001-7626-756X \\ Célia Regina Maio PINZAN-VERCELINO² \\ (i) https://orcid.org/0000-0002-5419-0079 \\ Arnaldo PINZAN' \\ (i) https://orcid.org/0000-0002-7195-5299 \\ Guilherme JANSON 1 \\ (i) https://orcid.org/0000-0001-5969-5175
}

Submitted: April 10, 2019 - Revised and accepted: August 11, 2019

凶mariapseminario@gmail.com

How to cite: Storniolo-Souza JM, Seminario MP, Pinzan-Vercelino CRM, Pinzan A, Janson G - McNamara analysis cephalometric parameters in White-Brazilians, Japanese and Japanese-Brazilians with normal occlusion. Dental Press J Orthod. 2021;26(1):e2119133.

(1) Universidade de São Paulo, Faculdade de Odontologia de Bauru, Departamento de Ortodontia (Bauru/SP, Brazil).

(2) Universidade Ceuma, Departamento de Ortodontia (São Luis/ MA, Brazil). 


\section{ABSTRACT}

Introduction: McNamara's Jr. cephalometric analysis is a tool to diagnose dental and skeletal discrepancies and is widely used, guiding diagnosis for surgical procedures to be performed or for the use of functional devices. Few studies have shown that different ethnic groups have different cephalometric patterns. Thus, single characteristics should be respected to support the diagnosis and to help the treatment plan for different ethnic groups and their different patterns of miscegenation.

Objective: Obtain normal values for McNamara's cephalometric analysis for adolescent Japanese-Brazilian descents with normal occlusion, as well as to compare this sample with similar samples of White-Brazilian and Japanese.

Methods: Lateral headfilms from 40 White-Brazilian, 33 Japanese and 32 Japanese-Brazilian descents were selected. The three groups were composed byindividuals with normal occlusion, well-balanced profiles and were separated by sex. The data were statistically analyzed with ANOVA, $t$-test, ANCOVA and MANCOVA tests.

Results: White-Brazilian males had significantly greater nasolabial angle than Japanese males. Japanese-Brazilian displayed an intermediate value between White-Brazilian and Japanese.

Conclusion: White-Brazilian, Japanese and Japanese-Brazilian present different cephalometric characteristics of McNamara analysis. Japanese males have a significantly more acute nasolabial angle than White-Brazilian subjects.

Keywords: Ethnic groups. Cephalometry. Diagnosis. 


\section{RESUMO}

Introdução: A análise cefalométrica de McNamara Jr. é uma ferramenta amplamente utilizada para o diagnóstico das discrepâncias dentárias e esqueléticas, principalmente porque fornece um diagnóstico que orienta os procedimentos cirúrgicos a serem realizados ou a utilização de aparelhos funcionais. Estudos têm demonstrado que diferentes grupos étnicos apresentam padrões cefalométricos distintos. Portanto, as características próprias dos indivíduos devem ser respeitadas, para suportar o diagnóstico e facilitar o plano de tratamento, entre as diferentes etnias e seus diferentes padrões de miscigenação. Objetivo: Determinar os valores médios de normalidade das grandezas cefalométricas relacionadas à análise de McNamara em jovens mestiços nipo-brasileiros, com oclusão normal, descendentes de japoneses e brasileiros, e comparar os resultados das variáveis com amostras de jovens brasileiros leucodermas e xantodermas que apresentem as mesmas características. Métodos: Foram selecionadas 40 telerradiografias de jovens leucodermas, 33 de xantodermas e 32 de nipo-brasileiros. As três amostras foram constituídas de indivíduos com oclusão normal e face bem balanceada, e foram divididas por sexo. Os dados foram estatisticamente analisados utilizando ANOVA, teste $t$, ANCOVA e MANOVA. Resultados: Os leucodermas apresentaram o ângulo nasolabial significativamente maior, comparados aos japoneses, no sexo masculino; enquanto os nipo-brasileiros apresentaram um valor intermediário entre os leucodermas e xantodermas. Conclusão: Os grupos de leucodermas, xantodermas e nipo-brasileiros apresentaram diferentes características cefalométricas da análise de McNamara. Os xantodermas no sexo masculino tiveram o ângulo nasolabial significativamente mais agudo, quando comparados com os leucodermas.

Palavras-chave: Grupos étnicos. Cefalometria. Diagnóstico. 


\section{INTRODUCTION}

In Orthodontics, several resources are available to aid diagnosis

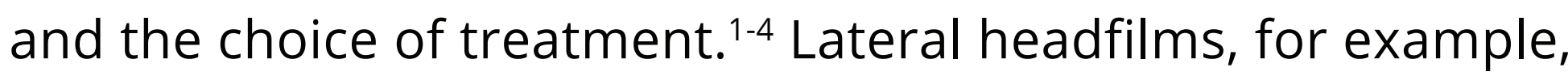
have been very useful in determining a more precise diagnosis, because radiograph images can now be reproduced with a minimum of distortion, facilitating orthodontic evaluation.

In 1941, Margolis ${ }^{5}$ presented an evaluation method that allowed the study of the facial outline, the mandible and the facial bones and their relationship with the teeth before and after orthodontic treatment, using cephalometric lateral headfilms and a profile photograph. In 1943, he verified that the incisor mandibular plane angle (IMPA) had to be $90^{\circ}$ in a pleasant skeletal pattern. ${ }^{3}$

Nowadays, it is known that cephalometric analysis does not serve as a fixed and unique parameter for the examination of an individual and in the determination of orthodontic diagnosis and planning. ${ }^{6}$

McNamara Jr. analysis is widely known among orthodontists. ${ }^{7}$ It has some advantages over other analyzes, such as linear evaluations of apical base discrepancy and dental to apical base discrepancies. This analysis assists in the diagnosis and treatment planning of orthopedic or surgical cases. 
Many of the studies on orthodontic cephalometric analyzes were based on samples of North American individuals, of essentially Anglo-Saxon origin. Thus, in view of the vast miscegenation of the world population, there is a need for research to adapt the cephalometric values found in White-Brazilians to different ethnic groups.

Population migration between different countries increases each year and, currently, Brazil is the country with the largest number of Japanese outside Japan. Based on that, it is extremely important to differentiate the variations that dento-skeletal structures may present due to the union between different ethnic groups. Because of the considerable increase of the Japanese-Brazilian population, there is a need for studies to support the diagnosis and facilitate the treatment plan for these group.

Therefore, the main purpose of this study is to compare three ethnic groups, White Brazilian, Japanese and JapaneseBrazilian, regarding the parameters of McNamara's cephalometric analysis.

\section{MATERIAL AND METHODS}

This study was approved by the Ethics in Research Committee of Universidade de São Paulo (USP, Brazil), under protocol number 080/2009. 
The sample selection criteria included pleasing and balanced profiles with passive lip competence, facial symmetry, presence of normal occlusion or incipient Angle Class I malocclusion with normal overjet-overbite, absence or a minimal crowding of less than $2 \mathrm{~mm}$, presence of all permanent teeth (except the third molars), as judged using study models.

In order to confirm the absence of racial miscegenation, the grandparents and parents of the White-Brazilian and Japanese samples should not have had any miscegenation. The Japanese-Brazilian sample should be descendant of both Brazilians and Japanese, without previous miscegenation.

The White-Brazilian sample comprised 40 lateral headfilms of 20 females (mean age $13.70 \pm 0.87$ years) and 20 males (mean age $13.57 \pm 1.03$ years), from the files of the Orthodontic Department at Faculdade de Odontologia de Bauru, Universidade de São Paulo.

The Japanese sample consisted of 33 lateral head films of 17 females (mean age $15.65 \pm 2.45$ years) and 16 males (mean age $15.56 \pm 2.51$ years) whose parents and grandparents were born in Japan (excluding Okinawa Island). 
The Japanese-Brazilian sample was constituted by 32 lateral headfilms of 17 females (mean age $13.22 \pm 1.04$ years) and 15 males (mean age of $14.79 \pm 1.01$ years). The inclusion criteria were the same as the other groups but in this case, all had to be children or grandchildren from the union of Japanese and White-Brazilians.

\section{CEPHALOMETRIC ANALYSIS}

The lateral headfilms were taken with the teeth in maximum intercuspation, in accordance with the norms of the Discipline of Radiology of the institution.

All radiographs were traced by hand on acetate paper sheets of $17.5 \times 17.5 \mathrm{~cm}$, with $0.5-\mathrm{mm}$ pencil, and a semi-rigid polypropylene black molding adapted to the negatoscope with the objective of concentrating the light to promote accurate visualization of the anatomical areas of interest.

The McNamara Jr. cephalometric variables were identified according to Table 1. The variables constructed with these landmarks are illustrated and described in Figures 1 to 3. 


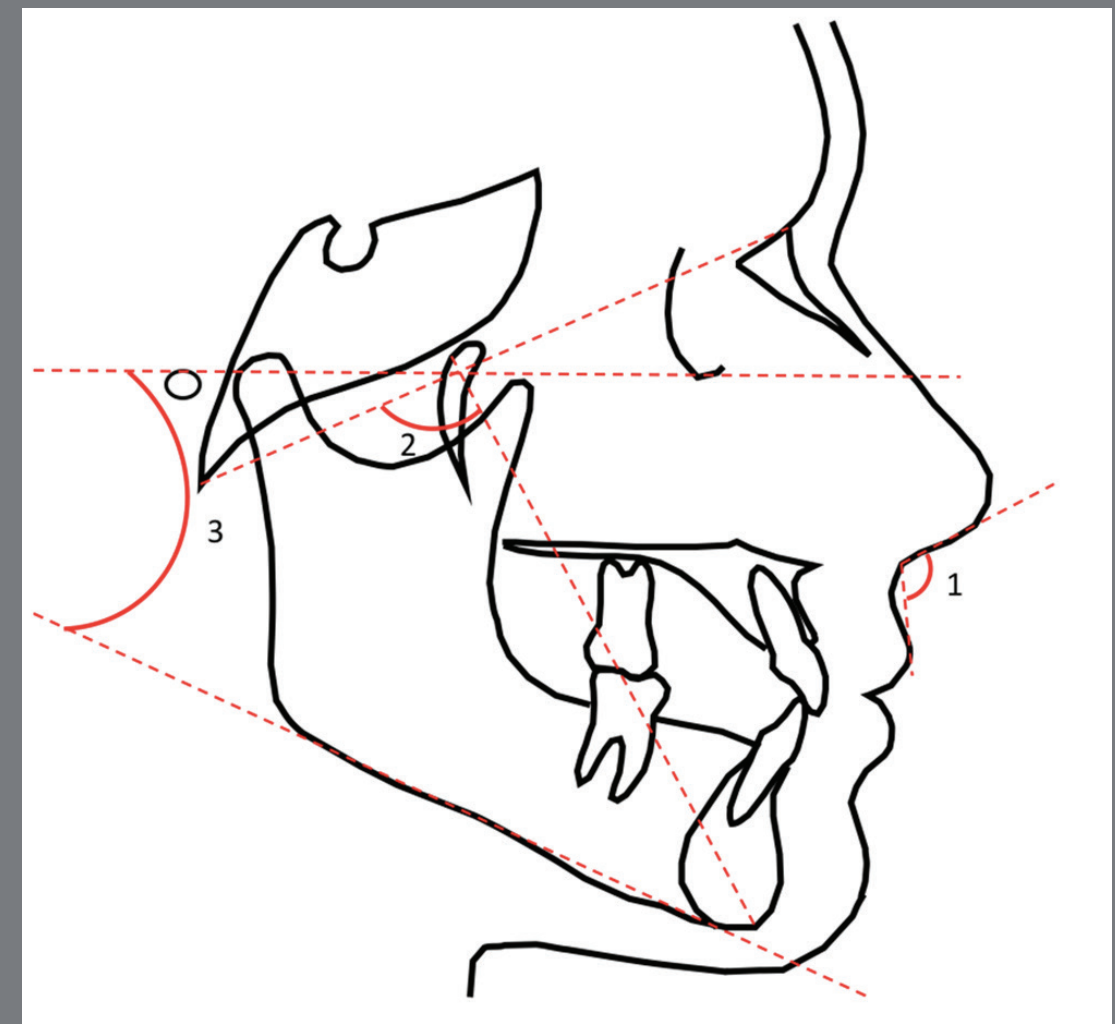

Figure 1: Angular measurements: 1) Nasolabial angle (Prn'.Sn.Ls); 2) Facial axis angle (BaN.PtGn); 3) Mandibular plane angle (PoOr.GoMe). Source: McNamara Jr, ${ }^{7} 1984$.

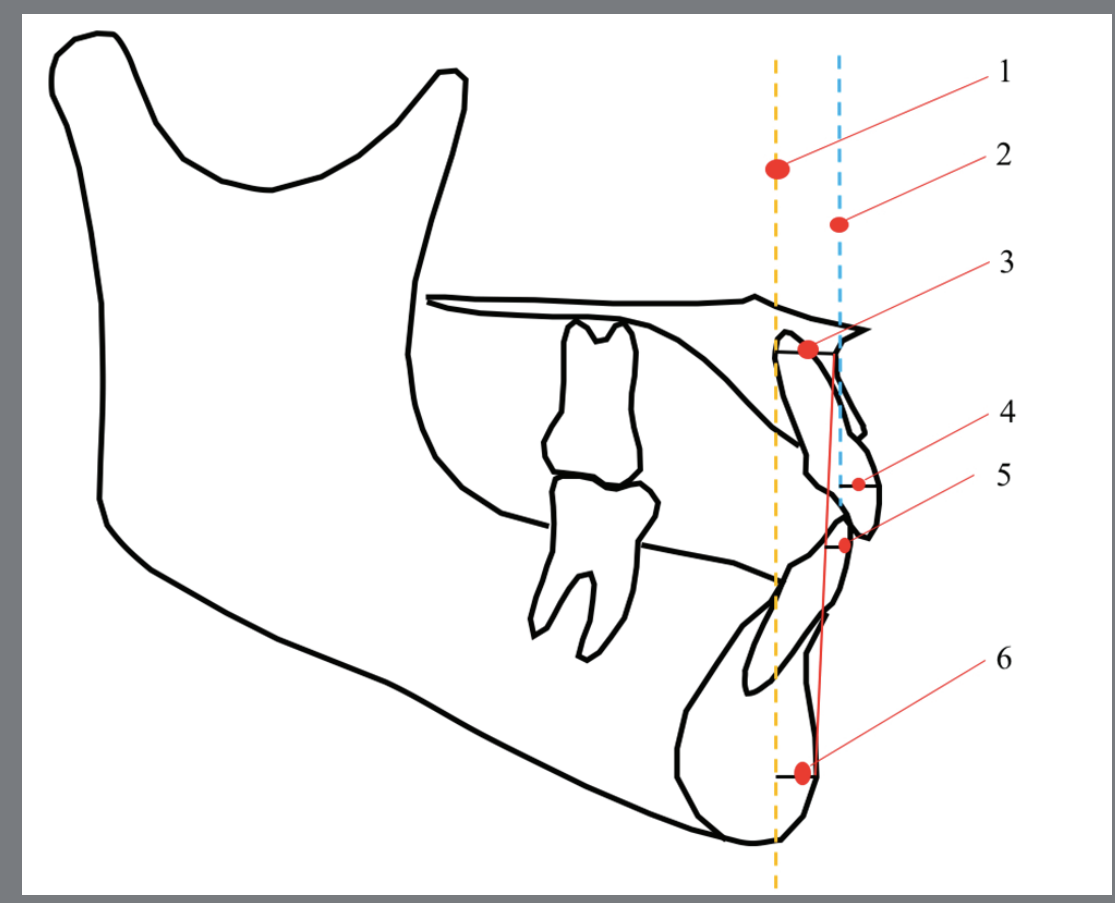

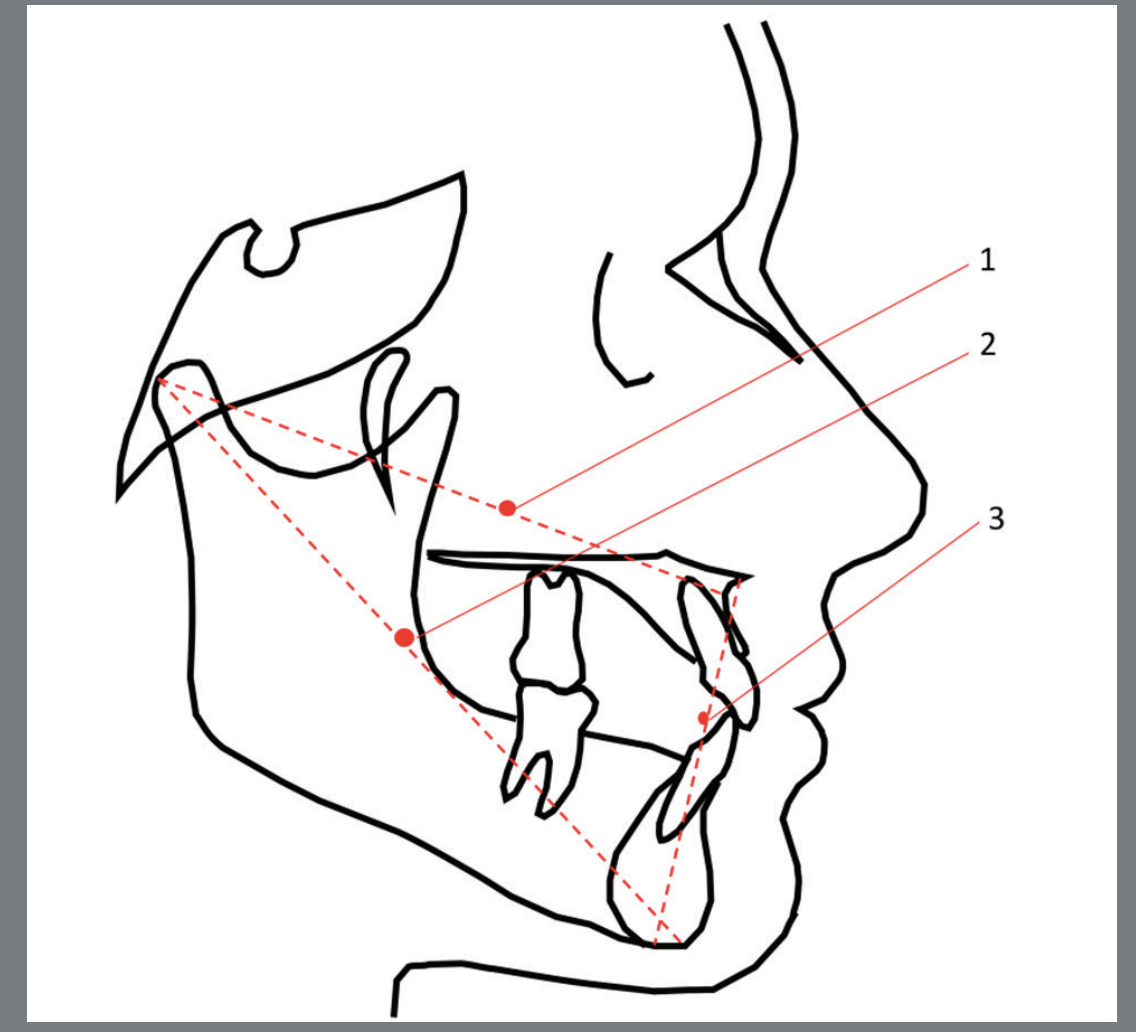

Figure 2: Reference lines and planes: 1) Midfacial length (Co-A); 2) Mandibular length (Co-Me); 3) Lower Anterior Facial Height (ANS-Me). Source: McNamara Jr, 1984.

Figure 3: Reference lines: 1) Nperp, 2) Aperp, 3) A-Nperp, 4) Upper incisor to Point A vertical, 5) Lower incisor to A-Po line, 6) P-Nperp. Source: McNamara Jr, 1984. 
Table 1: McNamara cephalometric analysis variables.

\begin{tabular}{|c|c|}
\hline \multicolumn{2}{|r|}{ Maxilla to cranial base } \\
\hline A-Nperp & Distance between point A to Nasion perpendicular \\
\hline \multicolumn{2}{|r|}{ Mandible to maxilla } \\
\hline Mandibular length & Distance between Co and Gn \\
\hline Midfacial length & Distance between Co and A \\
\hline Maxillo-mandibular difference & Difference between the mandibular and maxillary lengths (Co-Gn) - (Co-A) \\
\hline Lower Anterior Facial Height & Distance between ANS and Me \\
\hline Mandibular plane angle & $\begin{array}{l}\text { Angle between the anatomic Frankfurt horizontal plane and the line } \\
\text { drawn along Go and Me (mandibular plane angle) }\end{array}$ \\
\hline Facial axis angle & $\begin{array}{l}\text { Angle formed by the line constructed from the pterigomaxillary fis- } \\
\text { sure to Gn and the line constructed from Ba to point N }\end{array}$ \\
\hline \multicolumn{2}{|r|}{ Mandible to cranial base } \\
\hline P-Nperp & Distance between Pogonion and Nasion perpendicular \\
\hline \multicolumn{2}{|r|}{ Dentition } \\
\hline Upper incisor to Point A vertical & $\begin{array}{l}\text { Distance between the facial surface of upper incisor to the perpen- } \\
\text { dicular to Frankfurt plane, through point A }\end{array}$ \\
\hline Lower incisor to A-Po line & $\begin{array}{l}\text { Distance between the facial surface of mandibular incisor to the } \\
\text { A-Po line }\end{array}$ \\
\hline \multicolumn{2}{|r|}{ Soft tissue } \\
\hline Nasolabial angle & Angle formed between lines Prn'-Sn and Sn-Ls \\
\hline
\end{tabular}

Subsequently, the landmarks were digitized with a Numonics, AccuGrid A30TL digitizer (Numonics Corporation, Montgomeryville, PA, USA), and stored in a computer, by a single investigator. The variables were measured with Dentofacial Planner 7.02 software (Dentofacial Planner Software Inc., Toronto, Ontario, Canada).

\section{METHOD ERROR}

In order to evaluate the method error, 30\% of the sample was randomly selected and re-measured after a 30-day interval by the same investigator. To estimate the random errors, the 
formula proposed by Dalberg $\left(S^{2}=\Sigma d^{2} / 2 n\right.$, where $S^{2}$ is the error variance and " $\mathrm{d}$ " is the difference between two determinations of the same variable) was applied. Systematic errors were evaluated with dependent $t$-tests, at $p<0.05 .{ }^{9}$

\section{STATISTICAL ANALYSES}

Normal distribution of the variables was evaluated with Kolmogorov-Smirnov tests. All variables presented normal distribution.

Sexual dimorphism within each ethnic group was evaluated with $t$-tests. Ethnic intergroup comparison within males and females was performed with ANCOVA, using the age as co-variable, followed by Tukey tests and multivariate analysis of covariance (MANCOVA).

\section{RESULTS}

The random errors ranged from $0.26 \mathrm{~mm}$ (Lower incisor to A-Po line) to $0.74 \mathrm{~mm}$ (P-Nperp), and from $0.63^{\circ}$ (Facial axis angle) to $1.6^{\circ}$ (Nasolabial angle), and were within acceptable ranges. ${ }^{10,11}$ There were no significant systematic errors.

The Japanese sample was significantly older than the JapaneseBrazilian sample (Table 2).

Japanese males presented significantly greater maxillary retrusion, mandibular and midfacial lengths, and maxillomandibular difference than females (Table 4). 
Table 2: Intergroup age comparison between White-Brazilian, Japanese and Japanese-Brazilian and between males and females in the same ethnic group (Anova followed by Tukey tests).

\begin{tabular}{|c|c|c|c|c|c|c|c|}
\hline & \multicolumn{2}{|c|}{ White- Brazilian } & \multicolumn{2}{|c|}{ Japanese } & \multicolumn{2}{|c|}{ Japanese-Brazilian } & \multirow{2}{*}{$p$} \\
\hline & Mean & SD & Mean & SD & Mean & SD & \\
\hline Age & $13.48^{A}$ & 0.89 & $15.30^{\mathrm{A}}$ & 1.37 & $13.32^{\mathrm{B}}$ & 1.44 & $0.000 *$ \\
\hline \multicolumn{8}{|c|}{ White-Brazilian } \\
\hline & \multicolumn{2}{|c|}{ Females } & \multicolumn{4}{|c|}{ Males } & \\
\hline \multirow{2}{*}{ Age } & Mean & SD & \multicolumn{2}{|c|}{ Mean } & \multicolumn{2}{|c|}{ SD } & \multirow{2}{*}{0.397} \\
\hline & 13.56 & 0.81 & \multicolumn{2}{|c|}{13.40} & \multicolumn{2}{|c|}{0.97} & \\
\hline \multicolumn{8}{|c|}{ Japanese } \\
\hline \multirow{2}{*}{ Age } & Mean & SD & \multicolumn{2}{|c|}{ Mean } & \multicolumn{2}{|c|}{ SD } & \multirow{2}{*}{0.830} \\
\hline & 15.28 & 1.43 & \multicolumn{2}{|c|}{15.32} & \multicolumn{2}{|c|}{1.35} & \\
\hline \multicolumn{8}{|c|}{ Japanese-Brazilian } \\
\hline \multirow{2}{*}{ Age } & Mean & SD & \multicolumn{2}{|c|}{ Mean } & \multicolumn{2}{|c|}{ SD } & \multirow{2}{*}{0.647} \\
\hline & 13.05 & 1.51 & \multicolumn{2}{|c|}{13.64} & \multicolumn{2}{|c|}{1.33} & \\
\hline
\end{tabular}

* Statistically significant at $p<0.05$. Different superscript letters show significant differences between the means, by the Tukey test.

Table 3: White-Brazilian inter-sex comparison (t-tests).

\begin{tabular}{|c|c|c|c|c|c|}
\hline \multicolumn{6}{|c|}{ White-Brazilian sample } \\
\hline \multirow{2}{*}{ Variable } & \multicolumn{2}{|c|}{ Female $(n=20)$} & \multicolumn{2}{|c|}{ Male $(n=20)$} & \multirow{2}{*}{$p$} \\
\hline & Mean & SD & Mean & SD & \\
\hline \multicolumn{6}{|c|}{ Maxilla to cranial base } \\
\hline A-Nperp & 0.24 & 3.57 & -0.77 & 3.33 & 0.365 \\
\hline \multicolumn{6}{|c|}{ Mandible to maxilla } \\
\hline Mandibular length (Co-Gn) & 111.43 & 4.03 & 112.35 & 5.38 & 0.544 \\
\hline Midfacial length (Co-A) & 85.53 & 3.22 & 87.00 & 4.45 & 0.237 \\
\hline Maxillo-mandibular difference & 25.29 & 3.19 & 25.35 & 3.95 & 0.619 \\
\hline Lower Anterior Face Height (ANS-Me) & 62.45 & 3.66 & 63.45 & 3.62 & 0.391 \\
\hline Mandibular plane angle (PoOr.GoMe) & 24.25 & 4.99 & 26.52 & 3.87 & 0.116 \\
\hline Facial axis angle (BaN.PtGn) & 90.41 & 3.07 & 90.98 & 2.35 & 0.514 \\
\hline \multicolumn{6}{|c|}{ Mandible to cranial base } \\
\hline P-Nperp & -2.06 & 6.59 & -4.49 & 4.59 & 0.185 \\
\hline \multicolumn{6}{|c|}{ Dentition } \\
\hline Upper incisor to Point A vertical & 4.24 & 1.62 & 3.65 & 2.20 & 0.340 \\
\hline Lower incisor to A-Po line & 2.43 & 1.67 & 2.19 & 2.01 & 0.690 \\
\hline \multicolumn{6}{|c|}{ Soft tissue } \\
\hline Nasolabial angle (Prn'.Sn.Ls) & 105.71 & 7.46 & 106.72 & 10.56 & 0.727 \\
\hline
\end{tabular}


Table 4: Japanese inter-sex comparison (t-tests).

\begin{tabular}{|c|c|c|c|c|c|}
\hline \multicolumn{6}{|c|}{ Japanese sample } \\
\hline \multirow{2}{*}{ Variable } & \multicolumn{2}{|c|}{ Female $(n=17)$} & \multicolumn{2}{|c|}{ Male $(n=16)$} & \multirow{2}{*}{$p$} \\
\hline & Mean & SD & Mean & SD & \\
\hline \multicolumn{6}{|c|}{ Maxilla to cranial base } \\
\hline A-Nperp & -0.05 & 2.37 & -2.09 & 2.28 & $0.017 *$ \\
\hline \multicolumn{6}{|c|}{ Mandible to maxilla } \\
\hline Mandibular length (Co-Gn) & 110.16 & 3.28 & 115.08 & 4.44 & $0.001 *$ \\
\hline Midfacial length (Co-A) & 84.08 & 2.90 & 86.54 & 3.64 & $0.039 *$ \\
\hline Maxillo-mandibular difference & 26.08 & 2.99 & 28.55 & 3.80 & $0.046 *$ \\
\hline Lower Anterior Facial Height (ANS-Me) & 63.27 & 6.55 & 66.36 & 3.90 & 0.112 \\
\hline Mandibular plane angle (PoOr.GoMe) & 27.39 & 6.88 & 26.89 & 5.28 & 0.817 \\
\hline Facial axis angle (BaN.PtGn) & 89.26 & 4.02 & 88.23 & 3.22 & 0.426 \\
\hline \multicolumn{6}{|c|}{ Mandible to cranial base } \\
\hline P-Nperp & -6.02 & 6.55 & -6.88 & 4.18 & 0.661 \\
\hline \multicolumn{6}{|c|}{ Dentition } \\
\hline Upper incisor to Point A vertical & 3.82 & 1.87 & 4.63 & 2.23 & 0.271 \\
\hline Lower incisor to A-Po line & 3.68 & 1.77 & 3.52 & 1.57 & 0.781 \\
\hline \multicolumn{6}{|c|}{ Soft tissues } \\
\hline Nasolabial angle (Prn'.Sn.Ls) & 101.12 & 10.49 & 96.16 & 7.61 & 0.132 \\
\hline
\end{tabular}

* Statistically significant at $p<0.05$.

Japanese-Brazilian males presented significantly greater lower anterior face height and mandibular retrusion than females (Table 5).

There were significant ethnic intergroup differences among females (Table 6).

White-Brazilians had significantly greater Nasolabial angle than Japanese and significant ethnic intergroup differences among males (Table 7). 
Table 5: Japanese-Brazilian inter-sex comparison (t-tests).

\begin{tabular}{|c|c|c|c|c|c|}
\hline \multicolumn{6}{|c|}{ Japanese-Brazilian sample } \\
\hline \multirow[t]{2}{*}{ Variable } & \multicolumn{2}{|c|}{ Female $n=17$} & \multicolumn{2}{|c|}{ Male $n=15$} & \multirow{2}{*}{$p$} \\
\hline & Mean & SD & Mean & SD & \\
\hline \multicolumn{6}{|c|}{ Maxilla to cranial base } \\
\hline A-Nperp & 0.86 & 1.88 & -1.33 & 3.97 & 0.051 \\
\hline \multicolumn{6}{|c|}{ Mandible to maxilla } \\
\hline Mandibular length (Co-Gn) & 111.46 & 5.59 & 114.99 & 7.49 & 0.139 \\
\hline Midface length (Co-A) & 84.22 & 3.05 & 86.83 & 5.49 & 0.102 \\
\hline Maxillo-mandibular difference & 27.24 & 4.38 & 28.13 & 5.18 & 0.601 \\
\hline Lower Anterior Facial Height (ANS-Me) & 62.36 & 2.58 & 66.89 & 5.10 & $0.003 *$ \\
\hline Mandibular plane angle (PoOr.GoMe) & 23.85 & 3.00 & 27.16 & 6.11 & 0.057 \\
\hline Facial axis angle (BaN.PtGn) & 91.10 & 2.53 & 88.93 & 4.54 & 0.099 \\
\hline \multicolumn{6}{|c|}{ Mandible to cranial base } \\
\hline P-Nperp & -0.58 & 4.39 & -6.05 & 6.95 & $0.011 *$ \\
\hline \multicolumn{6}{|c|}{ Dentition } \\
\hline Upper incisor to Point A vertical & 5.36 & 2.23 & 4.77 & 2.29 & 0.466 \\
\hline Lower incisor to A-Po line & 2.89 & 2.20 & 3.66 & 2.49 & 0.363 \\
\hline \multicolumn{6}{|c|}{ Soft tissues } \\
\hline Nasolabial angle (Prn'.Sn.Ls) & 99.69 & 9.28 & 102.56 & 12.16 & 0.456 \\
\hline
\end{tabular}

* Statistically significant $p<0.05$.

Table 6: Female intergroup comparisons (ANCOVA and Multivariate Test of Significance).

\begin{tabular}{|c|c|c|c|c|c|c|c|c|}
\hline \multirow[t]{2}{*}{ Variable } & \multicolumn{2}{|c|}{$\begin{array}{c}\text { White-Brazilians } \\
(n=20)\end{array}$} & \multicolumn{2}{|c|}{$\begin{array}{c}\text { Japanese } \\
(n=17)\end{array}$} & \multicolumn{2}{|c|}{$\begin{array}{c}\text { Japanese- } \\
\text { Brazilians }(n=17)\end{array}$} & \multirow[t]{2}{*}{$p$} & \multirow[t]{2}{*}{$p$} \\
\hline & Mean & SD & Mean & SD & Mean & SD & & \\
\hline \multicolumn{8}{|c|}{ Maxilla to cranial base } & \multirow{16}{*}{$0.009^{\dagger}$} \\
\hline A-Nperp & 0.24 & 3.57 & -0.05 & 2.36 & 0.86 & 1.88 & 0.762 & \\
\hline \multicolumn{8}{|c|}{ Mandible to maxilla } & \\
\hline Mandibular length (Co-Gn) & 111.43 & 4.03 & 110.16 & 3.28 & 111.46 & 5.59 & 0.073 & \\
\hline Midface length (Co-A) & 85.53 & 3.22 & 84.08 & 2.90 & 84.22 & 3.05 & 0.148 & \\
\hline Maxillo-mandibular difference & 25.92 & 3.19 & 26.08 & 2.99 & 27.24 & 4.38 & 0.165 & \\
\hline Lower Anterior Facial Height (ANS-Me) & 62.45 & 3.66 & 63.27 & 6.55 & 62.36 & 2.58 & 0.728 & \\
\hline Mandibular plane angle (PoOr.GoMe) & 24.25 & 4.99 & 27.39 & 6.88 & 23.85 & 3.00 & 0.170 & \\
\hline Facial axis angle (BaN.PtGn) & 90.41 & 3.08 & 89.26 & 4.02 & 91.11 & 2.53 & 0.622 & \\
\hline \multicolumn{8}{|c|}{ Mandible to cranial base } & \\
\hline P-Nperp & -2.06 & 6.59 & -6.02 & 6.55 & -0.58 & 4.39 & 0.059 & \\
\hline \multicolumn{8}{|c|}{ Dentition } & \\
\hline Upper incisor to Point A vertical & 4.24 & 1.62 & 3.82 & 1.87 & 5.36 & 2.23 & 0.183 & \\
\hline Lower incisor to A-Po line & 2.43 & 1.67 & 3.68 & 1.77 & 2.89 & 2.20 & 0.080 & \\
\hline \multicolumn{8}{|c|}{ Soft tissues } & \\
\hline Nasolabial angle (Prn'.Sn.Ls) & 105.71 & 7.46 & 101.12 & 10.49 & 99.69 & 9.28 & 0.074 & \\
\hline
\end{tabular}

${ }^{\dagger}$ Statistically significant at $p<0.05$ based on MANCOVA test. 
Table 7: Male intergroup comparisons (ANCOVA followed by Tukey tests and Multivariate Test of Significance).

\begin{tabular}{|c|c|c|c|c|c|c|c|c|}
\hline \multirow[t]{2}{*}{ Variable } & \multicolumn{2}{|c|}{$\begin{array}{l}\text { White-Brazilian } \\
\qquad(\mathrm{n}=20)\end{array}$} & \multicolumn{2}{|c|}{$\begin{array}{l}\text { Japanese } \\
(n=15)\end{array}$} & \multicolumn{2}{|c|}{$\begin{array}{c}\text { Japanese- } \\
\text { Brazilian }(n=16)\end{array}$} & \multirow[t]{2}{*}{$p$} & \multirow[t]{2}{*}{$p$} \\
\hline & Mean & SD & Mean & SD & Mean & SD & & \\
\hline \multicolumn{8}{|c|}{ Maxilla to cranial base } & \multirow{16}{*}{$0.049^{\dagger}$} \\
\hline A-Nperp & -2.09 & 2.28 & -0.77 & 3.33 & -1.33 & 3.97 & 0.802 & \\
\hline \multicolumn{8}{|c|}{ Mandible to maxilla } & \\
\hline Mandibular length (Co-Gn) & 112.35 & 5.38 & 115.08 & 4.44 & 114.99 & 7.49 & 0.786 & \\
\hline Midface length (Co-A) & 87.00 & 4.45 & 86.54 & 3.64 & 86.83 & 5.49 & 0.764 & \\
\hline Maxillo-mandibular difference & 25.35 & 3.95 & 28.55 & 3.80 & 28.13 & 5.18 & 0.336 & \\
\hline Lower Anterior Facial Height (ANS-Me) & 63.45 & 3.62 & 66.36 & 3.90 & 66.89 & 5.10 & 0.195 & \\
\hline Mandibular plane angle (PoOr.GoMe) & 26.52 & 3.87 & 26.89 & 5.28 & 27.16 & 6.11 & 0.927 & \\
\hline Facial axis angle (BaN.PtGn) & 90.98 & 2.35 & 88.23 & 3.22 & 88.93 & 4.54 & 0.075 & \\
\hline \multicolumn{8}{|c|}{ Mandible to cranial base } & \\
\hline P-Nperp & -4.49 & 4.59 & -6.88 & 4.18 & -6.05 & 6.95 & 0.543 & \\
\hline \multicolumn{8}{|c|}{ Dentition } & \\
\hline Upper incisor to Point A vertical & 3.65 & 2.20 & 4.63 & 2.23 & 4.77 & 2.29 & 0.311 & \\
\hline Lower incisor to A-Po line & 2.19 & 2.01 & 3.52 & 1.57 & 3.66 & 2.49 & 0.111 & \\
\hline \multicolumn{8}{|c|}{ Soft tissues } & \\
\hline Nasolabial angle (Prn'.Sn.Ls) & $106.72^{\mathrm{A}}$ & 10.56 & $96.16^{\mathrm{B}}$ & 7.61 & $102.56^{A . B}$ & 12.16 & $0.026 *$ & \\
\hline
\end{tabular}

* Statistically significant at $p<0.05$ based on ANCOVA test. ${ }^{\dagger}$ Statistically significant at $p<0.05$ based on MANCOVA test. Different superscript letters show significant differences between the means by the Tukey test.

\section{DISCUSSION}

\section{SAMPLE}

Study samples have widely varied in the number of subjects, such as that of Cotton, Takano and Wong, ${ }^{12}$ who used a sample of only 20 individuals, and Shishikura, ${ }^{13}$ who used 132 individuals. Although the Japanese sample had a mean age significantly greater than the White-Brazilian and JapaneseBrazilian samples, in order to obtain a sample with the highest possible number of individuals, statistics was adjusted for the 
comparison between the three groups, in order to establish if the age would present any influence on the cephalometric measurements of the ethnic group.

Differences were found between male and female in the literature and in the present study. ${ }^{11,14,15}$ For this reason, the ethnic group comparisons had to be separated by sex.

\section{SEX DIFFERENCE}

In the White-Brazilian sample, no significant differences between males and females were found (Table 3). Nevertheless, males presented higher values, compared to females. Similar findings were reported by Miyajima et al., ${ }^{16}$ indicating that the dentoskeletal variables in males and females with ideal occlusion tend to be larger in males.

There was significantly greater retrusion of the maxilla in males than in females in the Japanese sample (Table 4). These characteristics of the skeletal tissues were confirmed by previous research. ${ }^{17}$ The midfacial length (Co-A), mandibular length (Co-Gn) and the maxillo-mandibular difference were significantly larger in males than in females. Similar findings were reported by Miyajima et al. ${ }^{16}$ and Bronfman et al., ${ }^{18}$ who noticed significant sexual dimorphism in the midface and in mandibular length. Because the midface and the mandibular length were larger, the maxillo-mandibular difference was also larger in males than in females. 
The Japanese-Brazilian sample presented dimorphism for some skeletal variables, with the highest values found for males (Table 5). Males displayed significantly greater anterior facial height than females. Supporting the results obtained by loi et al., ${ }^{19}$ who concluded that Japanese males have significantly longer faces than Japanese females. Also, males showed the mandible statistically more retruded than females. Similar values were obtained in the literature by Alcalde et al. ${ }^{17}$

\section{ETHNIC DIFFERENCES}

The samples were separated by sex to obtain a more specific and useful cephalometric normative values of each ethnic group. $16,17,20-22$

In males and females, the lower anterior face height was not significantly different between the three samples, which corroborates with the results of Nezu et al. ${ }^{23}$ and Alcalde et al. ${ }^{17}$ (Tables 6 and 7).

No significant differences in the dentition variables between the three samples could be noticed (Tables 6 and 7). The results found by Sathler et al. ${ }^{24}$ also demonstrated no differences in the upper incisor position between the Japanese-Brazilian and Caucasian sample. However, findings of Miura et al.,25 Miyajima et al., ${ }^{16}$ and loi et al. ${ }^{19}$ found that Japanese-Brazilians have greater protrusion of the mandibular incisors. 
Among the studied samples, only the nasolabial angle in males was significantly more acute in Japanese than in WhiteBrazilian (Table 7). The Japanese-Brazilian presented an average value intermediate to the group of White-Brazilian and Japanese. These results coincide with Bronfman et al. ${ }^{18}$ and Miyajima et al., ${ }^{16}$ that also observed a more acute nasolabial angle in Japanese.

McNamara Jr. ${ }^{7}$ reports that separate evaluation of soft and skeletal tissues usually leads to the same diagnosis, so a patient with an acute nasolabial angle also has a protruded maxila. In this study, the male Japanese group that presented more acute nasolabial angle also had the greatest maxillary protrusion, which has been previously observed. ${ }^{24}$ In addittion, Miyajima et al. ${ }^{16}$ concluded that Japanese presents greater lip protrusion.

Results showed significant differences between White-Brazilian, Japanese and Japanese-Brazilian using MANCOVA test (Tables 6 and 7). This test compares the three ethnic groups comparing all the variables together, in order to find differences between them. Previous studies found differences between Caucasians and Japanese sample $16,18,24,25$ that confirm the present findings. Therefore, the orthodontist must be careful and individualize each ethnic group during diagnosis and treatment planning. ${ }^{26,27}$ 


\section{CONCLUSIONS}

"White-Brazilian, Japanese and Japanese-Brazilian have, in general, similar cephalometric characteristics of McNamara Jr. analysis.

» Japanese males have a significantly more acute nasolabial angle than White-Brazilian subjects.

» The findings of these study support that one cephalometric parameter is not appropriate to application in different ethnic groups because of the intergroups differences observed. 
AUTHORS' CONTRIBUTION

Juliana M. Storniolo-Souza (JMSS)

Maria Pia Seminario (MPS)

Célia R. M. Pinzan-Vercelino (CRMPV)

Arnaldo Pinzan (AP)

Guilherme Janson (GJ)
Conception or design of the study:

JMSS, AP, GJ.

Data acquisition, analysis or

interpretation:

JMSS, MPS, CRMPV, AP, GJ.

Writing the article:

JMSS, MPS, GJ.

Critical revision of the article:

JMSS, MPS, CRMPV, AP, GJ.

Final approval of the article:

JMSS, MPS, CRMPV, AP, GJ.

The authors report no commercial, proprietary or financial interest in the products or companies described in this article. 


\section{REFERENCES}

1. $\quad$ Burstone C. The integumental profile. Am J Orthod. 1958;44(1):1-25.

2. Stoner M. A photometric analysis of the facial profile. Am J Orthod. 1955;41(6):453-69.

3. Margolis $\mathrm{H}$. The axial inclination of the mandibular incisors. Am J Orthod Oral Surg. 1943;29(10):571-94.

4. Albino JE, Tedesco LA. Esthetic need for orthodontic treatment. In: Melsen B, editor. Current Controversies in orthodontics. Chicago, IL: Quintessence, 1991. p. 11-24.

5. Margolis H. Composite x-ray photographs. Am J Orthod Oral Surg. 1941;27(12):717-22.

6. Arnett GW, Bergman RT. Facial keys to orthodontic diagnosis and treatment planning--Part II. Am J Orthod Dentofacial Orthop. 1993;103(5):395-411.

7. McNamara Jr. JA. A method of cephalometric evaluation. Am J Orthod. 1984;86(6):449-69.

8. Dahlberg G. Statistical methods for medical and biological students. Br Med J. 1940;2(4158):358-9.

9. Houston WJ. The analysis of errors in orthodontic measurements. Am J Orthod. 1983;83(5):382-90.

10. Midtgard J, Bjork G, Linder-Aronson S. Reproducibility of cephalometric landmarks and errors of measurements of cephalometric cranial distances. Angle Orthod. 1974;44:56-61. 
11. Wu J, Hagg U, Rabie AB. Chinese norms of McNamara's cephalometric analysis. Angle Orthod. 2007;77(1):12-20.

12. Cotton WN, Takano WS, Wong WM. The Downs analysis applied to three other ethnic groups. Angle Orthod. 1951;21(4):213-20.

13. Shishikura K. [The study on measurements of hard and soft tissues by cephalograms--particularly on normal and Class I occlusion among Japanese adults]. Nihon Kyosei Shika Gakkai Zasshi. 1969;28:263-73.

14. Huang WJ, Taylor RW, Dasanayake AP. Determining cephalometric norms for Caucasians and African Americans in Birmingham. Angle Orthod. 1998;68(6):503-11.

15. Lee JJ, Ramirez SG, Will MJ. Gender and racial variations in cephalometric analysis. Otolaryngol Head Neck Surg. 1997;117(4):326-9.

16. Miyajima K, McNamara Jr. JA, Kimura T, Murata S, lizuka T. Craniofacial structure of Japanese and European-American adults with normal occlusions and well-balanced faces. Am J Orthod Dentofacial Orthop. 1996;110(4):431-8.

17. Alcalde RE, Jinno T, Pogrel MA, Matsumura T. Cephalometric norms in Japanese adults. J Oral Maxillofac Surg. 1998;56(2):129-34.

18. Bronfman CN, Janson G, Pinzan A, Rocha TL. Cephalometric norms and esthetic profile preference for the Japanese: a systematic review. Dental Press J Orthod. 2015;20(6):43-51.

19. Ioi H, Nakata S, Nakasima A, Counts AL. Comparison of cephalometric norms between Japanese and Caucasian adults in antero-posterior and vertical dimension. Eur J Orthod. 2007;29:493-9. 
20. Qamruddin I, Alam MK, Shahid F, Tanveer S, Mukhtiar M, Asim Z. Assessment of gender dimorphism on sagittal cephalometry in Pakistani population. J Coll Physicians Surg Pak. 2016;26(5):390-3.

21. Todorova-Plachiyska KG, Stoilova-Todorova MG. Lateral Cephalometric Study in Adult Bulgarians with Normal Occlusion. Folia Med (Plovdiv) 2018;60(1):141-6.

22. Scavone Jr. H, Trevisan Jr. H, Garib DG, Ferreira FV. Facial profile evaluation in Japanese-Brazilian adults with normal occlusions and well-balanced faces. Am J Orthod Dentofacial Orthop. 2006;129(6):721.e1-5.

23. Nezu H, Nagata K, Yoshida Y, Kosaka H, Kikuchi M. Cephalometric comparison of clinical norms between the Japanese and Caucasians. Nihon Kyosei Shika Gakkai Zasshi. 1982;41(3):450-65.

24. Sathler R, Pinzan A, Fernandes TM, Almeida RR, Henriques JF. Comparative study of dental cephalometric patterns of JapaneseBrazilian, Caucasian and mongoloid patients. Dental Press J Orthod. 2014;19(4):50-7.

25. Miura F, Inoue N, Suzuki K. Cephalometric standards for Japanese according to the Steiner analysis. Am J Orthod. 1965;51:288-95.

26. Tweed C. Indications for the extraction of teeth in orthodontic procedure. Am J Orthod. Oral Surg. 1944;30(8):405-28.

27. Downs W. Variations in facial relationships: their significance in treatment and prognosis. Am J Orthod. 1948;34(10):812-40. 